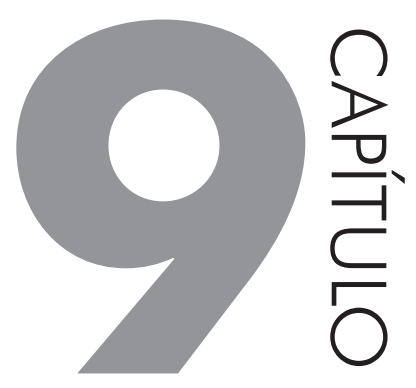

\title{
A TUTORIA COMO DESAFIO PARA OS NOVOS RUMOS EDUCACIONAIS
}

\section{JULIANA SIQUEIRA SERCUNDES}

\section{SÍNTESE DO PERCURSO}

Iniciei a Tutoria um pouco mais jovem. Ainda estava na graduação quando fui convidada pelos professores da UFPE Joaquim Liberalquino e Cacilda Andrade para fazer parte de uma experiência de curso de capacitação em nível profissional para auditores internos do Ministério da Educação, através do projeto Ensinar que estava localizado na Biblioteca Central da UFPE. Foi um projeto de sucesso e já naquela época havia me tornado coordenadora de Tutoria, pois gostava de demonstrar através de gráficos o resultado do acompanhamento dos cursistas e isso talvez tenha me dado certo destaque em relação aos demais. De fato, a educação a distância já me causava fascínio desde essa época. Mas foi algum tempo depois, já formada e servidora pública que me deparei com edital de seleção de Tutores para curso de graduação em Ciências Contábeis pela Universidade Aberta do Brasil. Foi a oportunidade de retomar aquele trabalho que havia marcado o início de minha trajetória profissional e da qual me orgulho de contribuir. Também não posso deixar de mencionar que conclui um mestrado profissional em Tecnologia e Gestão em EaD pela Universidade Federal Rural de Pernambuco (UFRPE), o que me ajudou ainda mais a conhecer esse processo de ensino-aprendizagem. 


\section{FATO MARCANTE}

Um fato que considero marcante ocorreu no início de minha trajetória, quando em determinado encontro presencial, um dos cursistas me falou que eu era exatamente do jeito que ele imaginava. Achei muito interessante essa percepção de imaginar o outro pela forma de tratar, de estimular, e de cobrar. Naquela época, onde o contato era praticamente apenas por mensagem em texto, foi uma celebração encontrá-los e conhecê-los um pouco melhor.

\section{MÉTODO POTENTE UTILIZADO NO PROCESSO DE ENSINO-APRENDIZAGEM}

Em minha experiência, o método que considero mais potente é a presença forte e constante no fórum para debates e dúvidas. Entendo que ainda é preciso evoluir muito em outras tantas ferramentas existentes, mas o fórum permite a troca de conhecimento, o debate, a crítica e ainda deixa o registro facilmente acessível a todos os interessados. No fórum podemos tirar uma dúvida prontamente ou motivarmos os demais a acrescentarem algo, promovendo muitas vezes construção mútua de conhecimento.

Em tempos de correria e horários desencontrados, acredito que essa seja a forma mais eficiente de contato, pois permite a participação, ainda que em momentos diferentes, de todos os cursistas e mediadores. Aliado a isso, é necessário estar sempre presente, pois acredito que os alunos necessitam de cobrança, de incentivo, de estímulos e especialmente de respostas.

Não tenho tido sucesso com outras ferramentas, como chats ou mensagens pois é difícil conciliar os horários em turmas tão heterogêneas e nem sempre as mensagens atendem as necessidades da nossa atuação.

\section{LIMITAÇÕES}

Lidamos diariamente com algumas limitações da nossa atuação, as quais, algumas delas não são exclusivas da educação a distância. Primeiramente acredito que as ferramentas disponíveis para serem utilizadas no ambiente não atendem efetivamente as necessidades dos professores, Tutores e alunos, e por isso ficamos mediando conflitos de ansiedades de alunos que cobram o uso de tecnologias diversas das que estão disponíveis, cobrança pelo uso de redes sociais ou mesmo de bate papos por telefone.

Além disso, percebo uma necessidade cada vez maior de motivar constantemente os cursistas. É uma dura tarefa com os recursos limitados de acompanhamento. O cursista precisa se manter autônomo, disciplinado e motivado para absorver conhecimento, e essas variáveis podem influenciar diretamente na evasão do curso. 
Outro ponto que ressalto é dependência excessiva do cursista pelo Tutor/ professor. É quase impossível atender as necessidades, por vezes exageradas, de respostas e feedbacks. Acho que o avanço da tecnologia impacta diretamente nessa necessidade por informações e contatos urgentes, quando temos outras atividades em curso e não conseguimos ser onipresentes.

Assim, minha percepção é a de que muitas vezes o Tutor absorve tarefas docentes, por vezes sendo confundido com o próprio professor da disciplina. $\mathrm{Ob}$ viamente, isso depende muito da forma de atuação do professor no ambiente virtual, o que pode influenciar diretamente nos resultados e na avaliação da disciplina. Assim, se o Tutor não tiver bem relacionado com o professor, com a matéria e com os alunos, os resultados podem ser bastante negativos.

\section{PERSPECTIVA DA TUTORIA COMO PROJETO EDUCACIONAL}

Como já ressaltado no item anterior, a depender da atuação do professor responsável, o cursista fica quase que totalmente dependente do Tutor. É preciso que haja maior engajamento no que se refere ao treinamento, elaboração de normativo e orientações amplamente divulgadas que especifique melhor as atividades e limites entre Tutoria e docência.

Por outro lado, vejo a tendência do Tutor como protagonista do processo de ensino a distância, pois ele atua como elo direto entre o cursista e o processo de ensino, e entre o cursista e o programa da disciplina.

É um desafio adquirir habilidades para motivar e se comunicar da forma mais compreensível para atender as atuais demandas dos cursistas no contexto de big datas e fake news, os quais estarão cada vez mais presentes nesse processo de ensino aprendizagem.

\section{AGRADECIMENTOS}

Gostaria de agradecer a todos os envolvidos nesse projeto educacional, que é o de expandir cada vez mais o ensino, ampliando o acesso aos que estão tão distantes e não tiveram condições de ingressar em uma Universidade Pública em outros moldes.

Especialmente aos Professores Cacilda Andrade e Joaquim Liberalquino que sempre depositaram apoio e confiança a mim durante todo meu envolvimento com a EAD e que são personagens principais na graduação de Ciências Contábeis e na UAB como um todo.

Ao Otacílio e a todos os envolvidos no curso de e-Tutoria, que trouxeram temas interessantes e estimulantes para tratarmos ao longo desse tempo. 
